\title{
Associated analysis of single nucleotide polymorphisms found on exon 3 of the IGF-1 gene with Tibetan miniature pig growth traits
}

\author{
M. Yue ${ }^{1 *}$, Y.G. Tian ${ }^{1 *}$, Y.J. Wang ${ }^{1}$, Y. Gu ${ }^{1}$, N. Bayaer ${ }^{2}$, Q. Hu² and W.W. Gu ${ }^{1,2}$ \\ ${ }^{1}$ Department of Laboratory Animal Center, Southern Medical University, \\ Guangzhou, China \\ ${ }^{2}$ Songshan Lake Pearl Laboratory Animal Science \& Technology Co., Ltd., \\ Dongguan, China \\ *These authors contributed equally to this study. \\ Corresponding author: W.W. Gu \\ E-mail: weiwanggu@126.com
}

Genet. Mol. Res. 13 (1): 1263-1269 (2014)

Received May 8, 2013

Accepted September 3, 2013

Published February 27, 2014

DOI http://dx.doi.org/10.4238/2014.February.27.11

\begin{abstract}
The IGF-1 gene is an important regulating factor that has a growth-promoting effect on growth hormone. The IGF-1 gene promotes muscle cell differentiation in the muscle cell formation process. The IGF-1 gene also regulates the growth of skeletal muscle during skeletal muscle growth. In addition, the IGF-1 gene plays an important role in the formation of mammals and poultry embryos, and the process of postnatal growth. The IGF-1 gene has been implicated as a candidate gene for the regulation of pig growth traits. We analyzed exon 3 of the IGF-1 gene polymorphism in Tibetan miniature pigs $(\mathrm{N}=128)$ by polymerase chain reaction-single-strand conformation polymorphism and DNA sequencing. One single nucleotide polymorphism (T40C) was found on exon 3 of the IGF-1 gene. Statistical analysis of genotype frequencies revealed that the $\mathrm{T}$ allele was dominant in Tibetan miniature pigs at the T40C locus. The association analysis showed that the IGF-1 mutation had an effect on the body weight, body length, and chest circumference
\end{abstract}


of pigs aged 6-8 months. In addition, the IGF-1 mutation had an effect on body weight in pigs aged $9-11$ months $(\mathrm{P}<0.05)$. We speculated that the pigs with the TT genotype grow more rapidly compared to those with the TC genotype. The TC genotype of the Tibetan miniature pig has a smaller body type. This information provides a theoretical basis for the genetic background of Tibetan miniature pigs.

Key words: Tibetan miniature pig; IGF-1 gene; SNP; Growth trait

\section{INTRODUCTION}

Growth hormone (GH) is secreted by the pituitary gland, and promotes metabolism and growth in the growth axis of mammalian metabolism. The function of promoting the growth of GH on target cells is mainly mediated by insulin-like growth factor (IGFs). GH and IGFs are hypothesized to play major roles via their respective specific receptors on the target cell membrane. The IGF system plays important roles in growth. The information obtained from the present study is important for elucidation of the regulatory mechanism of IGF system underlying growth, and for genetic improvement in pigs (Li et al., 2013). Therefore, it is very important to elucidate the function of hormone-based receptor binding activity and gene expression in the growth axis of mammalian metabolism (Buonomo and Klindt, 1993; Peng et al., 1998). The IGF-1 gene promotes muscle cell differentiation in the muscle cell formation process (Hembree et al., 1991; Buckingham et al., 2003; O'Sullivan et al., 2011). The IGF-1 gene also regulates the growth of skeletal muscle in the process of skeletal muscle growth (Doumit et al., 1993; Lamberson et al., 1995; Davis et al., 2002; Schlegel et al., 2010; Wang et al., 2011, 2012). In addition, the IGF-1 gene stimulates myoblast terminal differentiation by inducing the expression of the myogenin (MyoG) gene (Florini et al., 1991; Yano et al., 1999).

IGF-1 is important for regulating animal body growth, development, and metabolism. The porcine IGF-1 gene is located on chromosome 5 region q23-24 (Winterø et al., 1994; Xiao et al., 2009). The IGF-1 gene has been implicated as a candidate gene in the regulation of pig growth traits (Suzuki et al., 2004) Even though the mechanisms of human Laro-type dwarfism, sex-linked dwarfism in chickens, and other dwarfism conditions have been well studied (Godowski et al., 1989), the causes of dwarfism in miniature pigs have yet to be elucidated.

Miniature pigs are considered to be important model animals in biomedical research because of their anatomical and physiological similarities to humans and the relative ease with which they may be handled in experiments. The Tibetan miniature pig used in this study is the only type of mini-pig that is able to inhabit high elevation climatic conditions. Because other breeds cannot inhabit this geographical environment, the breed has remained pure. We analyzed IGF-1 polymorphisms in Tibetan miniature pigs by PCR-SSCP and DNA sequencing to further explore the effects of the IGF-1 gene on growth mechanisms.

\section{MATERIAL AND METHODS}

\section{Animals}

One hundred and twenty-eight blood samples from Tibetan miniature pigs (Department of Laboratory Animal Center, Southern Medical University, Guangzhou, China) were 
randomly collected. This study was carried out in strict accordance with the recommendations in the Guide for the Care and Use of Laboratory Animals of the National Institutes of Health. The animal use protocol was reviewed and approved by the Institutional Animal Care and Use Committee (IACUC) of Southern Medical University, China.

\section{Genomic DNA extraction}

Genomic DNA was extracted using Beijing Tiangen genomic DNA extraction kits. The purity and concentration of the DNA samples were confirmed with $1 \%$ agarose gel electrophoresis and ultraviolet spectrophotometry. The samples were diluted to $100 \mathrm{ng} / \mu \mathrm{L}$ and stored at $-20^{\circ} \mathrm{C}$.

\section{PCR}

PCR primers directed toward exon 3 of IGF-1 (GI: 347618789) were designed by Primer Premier 5.0 and synthesized by Invitrogen Trading (Shanghai, China) Co., Ltd. The following primer sequences were used: IGF1-F: 5'-ACAAGAACTACAGAATGTAGGAAG A-3', IGF1-R: 5'-AAGACAATGTTGGAATGTTTACT-3'.

PCRs were carried out in a total volume of $50 \mu \mathrm{L}$ containing $50 \mathrm{ng}$ template DNA, 2 $\mu \mathrm{L}$ primers $(10 \mu \mathrm{M}), 25 \mu \mathrm{L} 2 \mathrm{X}$ MasterMix (Taq $0.05 \mathrm{U} / \mu \mathrm{L}$ DNA polymerase, $4 \mathrm{mM} \mathrm{MgCl}$, and $4 \mathrm{mM}$ dNTPs), and $\mathrm{ddH}_{2} \mathrm{O}$ (Aidlab Biotechnologies Co., Ltd. Beijing, China), which was used to make up the volume to $50 \mu \mathrm{L}$. The conditions for PCR amplification included a denaturing step at $94^{\circ} \mathrm{C}$ for $5 \mathrm{~min}$, followed by 30 cycles at $94^{\circ} \mathrm{C}$ for $30 \mathrm{~s}, 1$ cycle at $50^{\circ} \mathrm{C}$ for $30 \mathrm{~s}, 1$ cycle at $72^{\circ} \mathrm{C}$ for $30 \mathrm{~s}$, and a final elongation at $72^{\circ} \mathrm{C}$ for $10 \mathrm{~min}$. PCR products were analyzed by agarose gel electrophoresis (1\% in TBE), and visualized under UV light after ethidium bromide staining.

\section{SSCP and sequencing}

The genotypes of 128 miniature pig individuals were ascertained by PCR-SSCP. A total of $5 \mu \mathrm{L}$ PCR product was mixed with $5 \mu \mathrm{L}$ of the denaturation solution, in addition to $1 \mu \mathrm{L}$ of the denaturation solution containing $5 \mathrm{mg}$ bromophenol blue, and $0.5 \mathrm{M} 400 \mu \mathrm{L}$ ethylenediaminetetraacetic acid disodium salt, and $9.6 \mathrm{~mL}$ formamide. The mixture was then denatured for $10 \mathrm{~min}$ at $98^{\circ} \mathrm{C}$, and rapidly chilled in an ice block. The samples were electrophoresed on $6 \%$ sodium dodecyl sulfate-polyacrylamide gel electrophoresis (SDS-PAGE). The electrophoresis was programmed to $200 \mathrm{~V}$ for $10 \mathrm{~min}$ for the first step, which was followed by a Silver Stain step of $100 \mathrm{~V}$ for $8 \mathrm{~h}$. A refrigerated circulator was used to maintain the temperature of the gels at $4^{\circ} \mathrm{C}$. Samples of different genotypes were sequenced by Invitrogen Trading Co., Ltd.

\section{Statistical analysis}

The PCR-SSCP results were corrected and analyzed using DNA STAR Lasergene v7.1, Chromas, SPSS13.0, and other biological software by searching for single nucleotide polymorphism (SNP) locus sites and identifying genotypes. The SNP loci, heterozygosity, and allele frequencies were predicted for exon 3 using the Popgene32 version 1.32 software. In addition, polymorphic information content (PIC) was determined using the PIC Calc 0.6 software. 


\section{RESULTS}

\section{PCR-SSCP}

An IGF-1 gene fragment of 161 bp (exon 3) was amplified by PCR, and resolved by $1 \%$ gel electrophoresis (Figure 1A). The genetic polymorphism of Tibetan miniature pigs was detected by SSCP in the locus of exon 3 (Figure 1B). The polymorphism of exon 3 was induced by T-C SNP at $40 \mathrm{bp}$ in the IGF-1 gene exon 3 (Figure 1C).
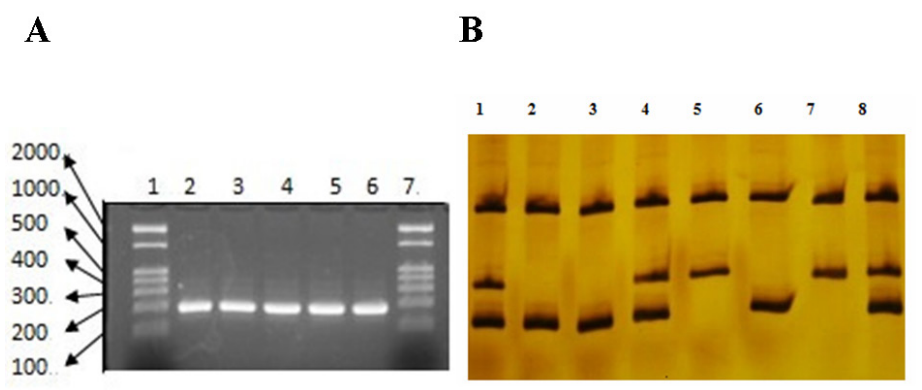

C

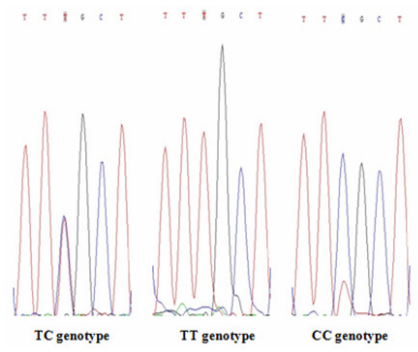

Figure 1. A. PCR results of exon 3 of the IGF-1 gene. Lanes 2- $6=$ PCR results of exon 3 of the IGF-1 gene (161 bp); lanes 1 and $7=2000$-bp DNA marker. B. Electrophoresis of PCR-SSCP for exon 3 of the IGF-1 gene; lanes 5 and $7=$ genotype TT; lanes 1, 4, and 8 = genotype TC; lanes 2, 3, and $6=$ genotype CC. C. Sequence comparisons of TT, TC, and CC genotypes.

\section{Genotypic and allelic frequencies}

The genotypic and allelic frequencies in the IGF-1 gene were statistically analyzed (Table 1). The variation in the distribution of these frequencies was tested for Tibetan miniature pigs (Table 2). Table 1 shows that the $\mathrm{T}$ allele was dominant in Tibetan miniature pigs at the T40C (PIC $=0.3266$ ) locus on exon 3 of the IGF-1 gene. The locus showed intermediate polymorphism, while the $\chi^{2}$ test results indicated that the locus in the population that fitted with the Hardy-Weinberg equilibrium was in disequilibrium $(\mathrm{P}=0.0040, \mathrm{P}<0.05)$.

\begin{tabular}{|c|c|c|c|c|c|c|c|c|c|}
\hline \multirow[t]{2}{*}{ Breed } & \multirow[t]{2}{*}{ Number } & \multirow[t]{2}{*}{ Locus } & \multicolumn{3}{|c|}{ Genotype frequency } & \multicolumn{2}{|c|}{ Allele frequency } & \multirow[t]{2}{*}{ PIC } & \multirow[t]{2}{*}{$\chi^{2}$} \\
\hline & & & TT & TC & $\mathrm{CC}$ & $\mathrm{T}$ & $\mathrm{C}$ & & \\
\hline TB & 128 & 40 & $0.4531(58)$ & $0.5156(66)$ & $0.0313(4)$ & 0.7109 & 0.2891 & 0.3266 & 8.292 \\
\hline
\end{tabular}

$\mathrm{TB}=$ Tibetan mini-pigs; PIC $=$ polymorphism information content.

Table 2. Genetic diversity of the IGF-1 gene in Tibetan mini-pigs.

\begin{tabular}{lcccccc}
\hline Gene & Exon & Number & $N_{\mathrm{A}}$ & $N_{\mathrm{E}}$ & $H_{\mathrm{O}}$ & $H_{\mathrm{E}}$ \\
\hline IGF-1 & 3 & 128 & 2.000 & 1.6978 & 0.5156 & 0.4142 \\
\hline
\end{tabular}

$N_{\mathrm{A}}=$ average number of alleles; $N_{\mathrm{E}}=$ effective number of alleles; $H_{\mathrm{O}}=$ observed heterozygosity; $H_{\mathrm{E}}=$ expected heterozygosity. 


\section{Relationship between growth traits and the IGF-1 gene polymorphism}

The association analysis results (Table 3 ) show that IGF-1 mutation affected the BW, $\mathrm{BL}$, and $\mathrm{CC}$ of miniature pigs aged 6-8 months. The IGF-1 mutation also affected the BW of miniature pigs aged 9-11 months. We speculated that pigs with the TT genotype grew more rapidly compared to those with the TC genotype. The TC genotype of Tibetan miniature pigs had a smaller body type.

\begin{tabular}{|c|c|c|c|c|c|c|c|}
\hline \multirow[t]{2}{*}{ Age (months) } & \multirow[t]{2}{*}{ Genotype } & \multirow[t]{2}{*}{ Number } & \multicolumn{5}{|c|}{ Trait } \\
\hline & & & BW (kg) & $\mathrm{BL}(\mathrm{cm})$ & WH $(\mathrm{cm})$ & $\mathrm{CC}(\mathrm{cm})$ & $\mathrm{AC}(\mathrm{cm})$ \\
\hline \multirow[t]{3}{*}{$3-5$} & TT & 18 & $9.42 \pm 3.16$ & $76.64 \pm 10.29$ & $33.39 \pm 3.03$ & $47.47 \pm 4.00$ & $46.72 \pm 5.96$ \\
\hline & $\mathrm{TC}$ & 36 & $9.21 \pm 2.45$ & $75.25 \pm 8.79$ & $33.88 \pm 2.64$ & $47.90 \pm 5.56$ & $49.15 \pm 6.86$ \\
\hline & $\mathrm{P}$ & & 0.801 & 0.628 & 0.567 & 0.746 & 0.187 \\
\hline \multirow[t]{4}{*}{$6-8$} & TT & 36 & $13.43 \pm 3.11^{*}$ & $85.17 \pm 9.45^{*}$ & $37.25 \pm 3.46$ & $54.51 \pm 5.25^{*}$ & $54.25 \pm 5.23$ \\
\hline & $\mathrm{TC}$ & 22 & $11.62 \pm 1.84 *$ & $76.98 \pm 8.25^{*}$ & $36.95 \pm 3.08$ & $50.84 \pm 2.21 *$ & $53.25 \pm 4.62$ \\
\hline & $\mathrm{CC}$ & 4 & $11.98 \pm 1.24$ & $80.50 \pm 0.82$ & $37.63 \pm 0.25$ & $52.25 \pm 1.19$ & $54.38 \pm 7.09$ \\
\hline & $\mathrm{P}$ & & 0.005 & 0.000 & 0.831 & 0.000 & 0.822 \\
\hline \multirow[t]{3}{*}{$9-11$} & TT & 4 & $23.63 \pm 4.03^{*}$ & $91.50 \pm 4.20$ & $51.50 \pm 8.70$ & $62.63 \pm 3.68$ & $63.13 \pm 3.40$ \\
\hline & TC & 8 & $17.04 \pm 3.74 *$ & $88.06 \pm 6.03$ & $42.75 \pm 4.86$ & $58.56 \pm 7.59$ & $59.44 \pm 5.73$ \\
\hline & $\mathrm{P}$ & & 0.036 & 0.282 & 0.135 & 0.241 & 0.195 \\
\hline
\end{tabular}

$\mathrm{BW}=$ body weight $\mathrm{BL}=$ body length $; \mathrm{WH}=$ wither height $\mathrm{CC}=$ chest circumference $\mathrm{AC}=$ abdomen circumference. *Means significantly different $(\mathrm{P}<0.05)$ between TT and TC.

\section{DISCUSSION}

The IGF-1 gene is an important candidate gene that regulates muscle growth and lipidosis; consequently, much research has focused on polymorphisms and associations of this gene. In this study, IGF-1 genotype frequencies indicate the presence of one SNP on exon 3 (161 bp) of Tibetan miniature pigs. The T allele was dominant in Tibetan miniature pigs at the T40C locus. The locus showed intermediate polymorphism, with the $\chi^{2}$ test results indicating that the locus in the population fitted with the Hardy-Weinberg equilibrium that was in disequilibrium $(\mathrm{P}=0.0040, \mathrm{P}<0.05)$. Of all the 128 Tibetan pig tests, 58 and 66 pigs had the TT and TC genotypes, respectively; however, only 4 pigs had the CC genotype.

The average PIC is an ideal index for assessing gene fragment polymorphisms. A PIC value of $>0.5$ indicates a highly polymorphic region, whereas a PIC value of $<0.25$ indicates a low polymorphism site. In comparison, $0.25<$ PIC $<0.5$ indicates a moderate polymorphic site (Godowski et al., 1989). The IGF-1 gene of Tibetan miniature pigs exhibits moderate polymorphism at T40C. The PIC of the IGF-1 gene was 0.3266; however, Hao et al. (2011) only located 1 SNP (G201A) with a PIC of $0.20<0.25$; hence, Tibetan miniature pigs exhibit low polymorphism.

Genetic heterozygosity indicates the proportion of the group with site heterozygotes at certain loci. The average heterozygosity of loci reflects the level of variation of a genetic structure, in which variability is directly correlated with heterozygosity and the ability to adapt to the environment (Hao et al., 2011). Small effective allele number and observed heterozygosity were observed in Tibetan miniature pigs, confirming that this population has relatively low genetic diversity. 
IGF-1 is involved in the endocrine regulation of animal growth and development. Numerous studies have shown that IGF-1 promotes the growth rate of experimental animals, such as growth stimulation by the injection of IGF-1 (Baker et al., 1993; Vickers et al., 2001). Our results showed that IGF-1 genes containing the TT genotype grew more rapidly compared to IGF-1 genes containing the TC genotype. The BW, BL, and CC of the two genotypes were significantly different $(\mathrm{P}<0.05)$. The $\mathrm{BW}, \mathrm{BL}$, and $\mathrm{CC}$ of the TT genotype were higher compared to the TC genotype of 6-8-month-old miniature pigs $(\mathrm{P}=0.005, \mathrm{P}=0.000)$. However, only the BW of the TT genotype was higher compared to the TC genotype in 9-11-month-old pigs (P $=0.036$ ). Based on these results, we speculate that the TC genotype of IGF-1 represents the selection genotype for smaller in size. This experiment was restricted by sample resource and number. Therefore, future experiments are required to verify the results of this research using a bigger population.

\section{ACKNOWLEDGMENTS}

Research supported by the Science and Technology Planning Project of Guangdong Province, China (\#2010A011200003, \#2010A030400001, \#2011B060300014).

\section{REFERENCES}

Baker J, Liu JP, Robertson EJ and Efstratiadis A (1993). Role of insulin-like growth factors in embryonic and postnatal growth. Cell 75: 73-82.

Buckingham M, Bajard L, Chang T, Daubas P, et al. (2003). The formation of skeletal muscle: from somite to limb. $J$. Anat. 202: 59-68.

Buonomo FC and Klindt J (1993). Ontogeny of growth hormone (GH), insulin-like growth factors (IGF-I and IGF-II) and IGF binding protein-2 (IGFBP-2) in genetically lean and obese swine. Domest. Anim. Endocrinol. 10: 257-265.

Davis TA, Fiorotto ML, Burrin DG, Vann RC, et al. (2002). Acute IGF-I infusion stimulates protein synthesis in skeletal muscle and other tissues of neonatal pigs. Am. J. Physiol. Endocrinol. Metab. 283: E638-E647.

Doumit ME, Cook DR and Merkel RA (1993). Fibroblast growth factor, epidermal growth factor, insulin-like growth factors, and platelet-derived growth factor-BB stimulate proliferation of clonally derived porcine myogenic satellite cells. J. Cell Physiol. 157: 326-332.

Florini JR, Ewton DZ and Roof SL (1991). Insulin-like growth factor-I stimulates terminal myogenic differentiation by induction of myogenin gene expression. Mol. Endocrinol. 5: 718-724.

Godowski PJ, Leung DW, Meacham LR, Galgani JP, et al. (1989). Characterization of the human growth hormone receptor gene and demonstration of a partial gene deletion in two patients with Laron-type dwarfism. Proc. Natl. Acad. Sci. U. S. A. 86: 8083-8087.

Hao LL, Yu H, Zhang Y, Sun SC, et al. (2011). Single nucleotide polymorphism analysis of exons 3 and 4 of IGF-1 gene in pigs. Genet. Mol. Res. 10: 1689-1695.

Hembree JR, Hathaway MR and Dayton WR (1991). Isolation and culture of fetal porcine myogenic cells and the effect of insulin, IGF-I, and sera on protein turnover in porcine myotube cultures. J. Anim. Sci. 69: 3241-3250.

Lamberson WR, Safranski TJ, Bates RO, Keisler DH, et al. (1995). Relationships of serum insulin-like growth factor I concentrations to growth, composition, and reproductive traits of swine. J. Anim. Sci. 73: 3241-3245.

Li Z, Wu Z, Ren G, Zhao Y, et al. (2013). Expression patterns of insulin-like growth factor system members and their correlations with growth and carcass traits in Landrace and Lantang pigs during postnatal development. Mol. Biol. Rep. 40: 3569-3576.

O’Sullivan JF, Leblond AL, Kelly G, Kumar AH, et al. (2011). Potent long-term cardioprotective effects of single lowdose insulin-like growth factor-1 treatment postmyocardial infarction. Circ. Cardiovasc. Interv. 4: 327-335.

Peng M, Abribat T, Calvo E, LeBel D, et al. (1998). Ontogeny of insulin-like growth factors (IGF), IGF binding proteins, IGF receptors, and growth hormone receptor mRNA levels in porcine pancreas. J. Anim. Sci. 76: 1178-1188.

Schlegel W, Halbauer D, Raimann A, Albrecht C, et al. (2010). IGF expression patterns and regulation in growth plate chondrocytes. Mol. Cell. Endocrinol. 327: 65-71. 
Suzuki K, Nakagawa M, Katoh K, Kadowaki H, et al. (2004). Genetic correlation between serum insulin-like growth factor-1 concentration and performance and meat quality traits in Duroc pigs. J. Anim. Sci. 82: 994-999.

Vickers MH, Ikenasio BA and Breier BH (2001). IGF-I treatment reduces hyperphagia, obesity, and hypertension in metabolic disorders induced by fetal programming. Endocrinology 142: 3964-3973.

Wang J, Zhu X, Li X, Wang W, et al. (2011). Effects of copper on proliferation and autocrine secretion of insulin-like growth factor-1 (IGF-1) and IGF-binding protein-3 (IGFBP-3) in chondrocytes from newborn pigs in vitro. Biol. Trace Elem. Res. 144: 588-596.

Wang J, Zhu X, Xie G, Zhang Y, et al. (2012). Effect of copper on the expression of IGF-1 from chondrocytes in newborn piglets in vitro. Biol. Trace Elem. Res. 148: 178-181.

Winterø AK, Fredholm M and Andersson L (1994). Assignment of the gene for porcine insulin-like growth factor 1 (IGF1) to chromosome 5 by linkage mapping. Anim. Genet. 25: 37-39.

Xiao S, Li S, Zhang J, Zhang S, et al. (2009). Cloning and characterization of class 1 and class 2 insulin-like growth factor-I mRNA in Songliao black pig. Mol. Biol. Rep. 36: 415-421.

Yano K, Bauchat JR, Liimatta MB, Clemmons DR, et al. (1999). Down-regulation of protein kinase C inhibits insulin-like growth factor I-induced vascular smooth muscle cell proliferation, migration, and gene expression. Endocrinology 140: 4622-4632. 